\title{
A Comparison of Health Plan- and Provider-Delivered Chronic Care Management Models on Patient Clinical Outcomes
}

\author{
Zhehui Luo, MS, $P h D^{7}$, Qiaoling Chen, $M S^{2}$, Ann M. Annis, PhD, RN², Gretchen Piatt, MPH, PhD', \\ Lee A. Green, MD, MPH ${ }^{5}$, Min Tao, PhD ${ }^{6}$, and Jodi Summers Holtrop, PhD, MCHES ${ }^{7}$ \\ 'Department of Epidemiology and Biostatistics, College of Human Medicine, Michigan State University, East Lansing, MI, USA; ${ }^{2}$ Department of \\ Research and Evaluation, Kaiser Permanente Sourthen California, Pasadena, CA, USA; ${ }^{3}$ VA Ann Arbor Healthcare System, Ann Arbor, MI, USA; \\ ${ }^{4}$ Department of Learning Health Sciences, University of Michigan, Ann Arbor, MI, USA; ${ }^{5}$ Department of Family Medicine, University of Alberta, \\ Edmonton, AB, Canada; ${ }^{6}$ Clinical Epidemiology and Biostatistics, Blue Cross Blue Shield of Michigan, Detroit, MI, USA; ${ }^{7}$ Department of Family \\ Medicine, University of Colorado, Aurora, CO, USA.
}

BACKGROUND: The real world implementation of chronic care management model varies greatly. One aspect of this variation is the delivery mode. Two contrasting strategies include provider-delivered care management (PDCM) and health plan-delivered care management (HPDCM).

OBJECTIVE: We aimed to compare the effectiveness of PDCM vs. HPDCM on improving clinical outcomes for patients with chronic diseases.

DESIGN: We used a quasi-experimental two-group prepost design using the difference-in-differences method.

PATIENTS: Commercially insured patients, with any of the five chronic diseases-congestive heart failure, chronic obstructive pulmonary disease, coronary heart disease, diabetes, or asthma, who were outreached to and engaged in either PDCM or HPDCM were included in the study.

MAIN MEASURES: Outreached patients were those who received an attempted or actual contact for enrollment in care management; and engaged patients were those who had one or more care management sessions/encounters with a care manager. Effectiveness measures included blood pressure, low density lipoprotein (LDL), weight loss, and hemoglobin Alc (for diabetic patients only). Primary endpoints were evaluated in the first year of follow-up.

KEY RESULTS: A total of 4,000 patients were clustered in 165 practices (31 in PDCM and 134 in HPDCM). The PDCM approach demonstrated a statistically significant improvement in the proportion of outreached patients whose LDL was under control: the proportion of patients with $\mathrm{LDL}<100 \mathrm{mg} / \mathrm{dL}$ increased by $3 \%$ for the PDCM group (95\% CI: $1 \%$ to $6 \%$ ) and $1 \%$ for the HPDCM group (95\% CI: $-2 \%$ to $5 \%$ ). However, the $2 \%$ difference in these improvements was not statistically significant $(95 \%$ CI: $-2 \%$ to $6 \%$ ). The HPDCM approach showed $3 \%$ [95 \% CI: $2 \%$ to $6 \%$ improvement in overall diabetes care among outreached patients and significant reduction in obesity rates compared to PDCM (4\%, $95 \%$ CI: $0.3 \%$ to $8 \%$ ).

CONCLUSIONS: Both care management delivery modes may be viable options for improving care for patients with

Qiaoling Chen: work completed while at Michigan State University.

Ann M. Annis: work completed while at Blue Cross Blue Shield of Michiaan

Received April 13, 2015

Revised August 31, 2015

Accepted February 1, 2016

Published online March 7, 2016 chronic diseases. In this commercially insured population, neither PDCM nor HPDCM resulted in substantial improvement in patients' clinical indicators in the first year. Different care management strategies within the provider-delivered programs need further investigation.

KEY WORDS: primary Care; care management; chronic Disease; comparative effectiveness.

J Gen Intern Med 31(7):762-70

DOI: $10.1007 / \mathrm{s} 11606-016-3617-2$

(C) Society of General Internal Medicine 2016

\section{INTRODUCTION}

Engaging patients with chronic diseases in self-management activities may improve their well-being and prevent costly medical complications. The potential health and economic returns of patient involvement in care has driven an expansion of programs that "assist consumers and their support system to become engaged in a collaborative process designed to manage medical/social/mental health conditions more effectively." 1 Commonly referred to as disease management programs, they are implemented by a number of health insurers and commercial health care companies. These programs primarily rely on telephonic intervention, are independent of the patient's usual health care setting, and have demonstrated some reductions in health care utilization and costs. ${ }^{2-4}$ Conversely, primary care providers (PCP) are increasingly offering chronic care management programs within their practices. ${ }^{5-7}$ Both insurer disease management and provider care management include patient education, goal setting, and self-management support. However, the latter has the advantage of integration and coordination with the patient's PCP, which may be key to improving health outcomes. ${ }^{8-12}$

Although each of the two aforementioned approaches has been evaluated independently, there is a lack of studies comparing them directly. In addition, the literature is inconsistent with regard to outcomes in natural care delivery settings. ${ }^{13-15}$ There appears to be much to learn about the effectiveness of these approaches and how they compare to each other. ${ }^{16}$ Initiatives in primary care, such as the Patient Centered Medical Home $(\mathrm{PCMH})$, encourage transforming the organization and 
delivery of primary care, ${ }^{17-19}$ by, for example, adding care managers. ${ }^{20,21}$ Given that practices will likely continue and increase participation in PCMH and similar efforts, evidence of care management's effectiveness in this setting is needed.

In 2010, a large Michigan health insurer with a health plan-delivered disease management program conducted a 2-year pilot program to support care management delivered in primary care settings. Subsequently, the Agency for Healthcare Research and Quality funded an evaluation study to compare the effectiveness between the two care management models, in terms of patient targeting and engagement in care management, as well as clinical and utilization outcomes. Patient engagement and utilization results are reported elsewhere. ${ }^{22,23}$ The focus of this paper is to compare the relative effectiveness of the two delivery modes on patient clinical outcomes. We hypothesized that provider-delivered care management (PDCM) is more effective than the health-plan delivered care management (HPDCM), due to the integration of care management in the primary care setting.

\section{METHODS \\ Care Management Interventions}

In efforts to improve the health of its members, the health plan in this study routinely administers HPDCM for members with at least one of five chronic diseases: congestive heart failure, chronic obstructive pulmonary disease, coronary heart disease, diabetes, or asthma. Employers contract with the health plan to deliver this program to qualified members. HPDCM is provided by dedicated nurses employed by and located at the health plan (centralized), who reach out to and engage eligible members via phone calls. Details of the HPDCM program are summarized in the last column of Table 1.

Aligned with its goal to promote the implementation of PCMHs, ${ }^{24}$ the health plan recognized that care management delivered within a primary care setting may increase engagement of members in their care and result in improvements in health outcomes and reductions in health care utilization and costs. Therefore, this health plan funded five physician organizations (POs) for a pilot PDCM program that was implemented from April 2010 through March 2012. The POs were

Table 1. Description of the PDCM and HPDCM Care Management Approaches

\begin{tabular}{|c|c|c|c|c|c|c|}
\hline \multirow[t]{2}{*}{$\overline{\text { Characteristics }}$} & \multicolumn{5}{|l|}{ PDCM } & \multirow[t]{2}{*}{$\overline{\mathrm{HPDCM}}$} \\
\hline & PO-A & PO-B & PO-C * & PO-D * & PO-E & \\
\hline$\overline{\text { Size of practice }{ }^{\dagger}}$ & Small to large & Very small to small & Small to very large & Very small to large & $\begin{array}{l}\text { Medium to } \\
\text { very large }\end{array}$ & $\begin{array}{l}\text { Small to very } \\
\text { large }\end{array}$ \\
\hline $\begin{array}{l}\text { Practice } \\
\text { discipline }\end{array}$ & Family medicine & Family medicine & $\begin{array}{l}\text { Family or internal } \\
\text { medicine }\end{array}$ & $\begin{array}{l}\text { Family or internal } \\
\text { medicine }\end{array}$ & $\begin{array}{l}\text { Family or } \\
\text { internal } \\
\text { medicine }\end{array}$ & $\begin{array}{l}\text { Family, } \\
\text { pediatric or } \\
\text { adult }\end{array}$ \\
\hline $\begin{array}{l}\text { Location of care } \\
\text { manager }\end{array}$ & $\begin{array}{l}\text { Centralized and } \\
\text { embedded }\end{array}$ & Centralized & Embedded & $\begin{array}{l}\text { Centralized and } \\
\text { embedded }\end{array}$ & Embedded & Centralized \\
\hline $\begin{array}{l}\text { Care } \\
\text { management } \\
\text { offering mode }\end{array}$ & CM via phone & $\begin{array}{l}\text { Provider referral to } \\
\mathrm{CM} \text {; CM via phone }\end{array}$ & $\begin{array}{l}\text { Provider offers } \\
\text { during visit; CM } \\
\text { sees patients right } \\
\text { after; or CM via } \\
\text { phone }\end{array}$ & $\begin{array}{l}\text { Provider offers } \\
\text { during visit; CM } \\
\text { sees patients right } \\
\text { after; or CM via } \\
\text { phone }\end{array}$ & $\begin{array}{l}\text { Provider offers } \\
\text { during visit; } \\
\text { CM sees } \\
\text { patients right } \\
\text { after }\end{array}$ & $\begin{array}{l}\text { CM via phone } \\
\text { or recorded } \\
\text { message }\end{array}$ \\
\hline $\begin{array}{l}\text { Care } \\
\text { management } \\
\text { delivering mode }\end{array}$ & Phone & Phone & $\begin{array}{l}\text { In person at } \\
\text { practice and phone }\end{array}$ & $\begin{array}{l}\text { In person at } \\
\text { practice and phone }\end{array}$ & $\begin{array}{l}\text { In person at } \\
\text { practice and } \\
\text { phone }\end{array}$ & Phone \\
\hline $\begin{array}{l}\text { CM background } \\
\text { and training }\end{array}$ & $\mathrm{RN}$ & $\mathrm{RN}$ & $\begin{array}{l}\mathrm{RN} \text {, nurse } \\
\text { practitioner or } \\
\text { PharmD }\end{array}$ & $\begin{array}{l}\mathrm{RN} \text {, licensed } \\
\text { practical nurse or } \\
\text { medical assistant }\end{array}$ & RN & $\mathrm{RN}$ \\
\hline $\begin{array}{l}\text { Care } \\
\text { management } \\
\text { activities }\end{array}$ & \multicolumn{6}{|c|}{ Chronic disease education, self-management support, motivational interviewing, goal setting, and health coaching } \\
\hline Focus of efforts & $\begin{array}{l}\text { Complex chronic } \\
\text { disease; diabetes }\end{array}$ & $\begin{array}{l}\text { Chronic conditions and } \\
\text { health promotion } \\
\text { (weight loss, smoking } \\
\text { cessation) }\end{array}$ & $\begin{array}{l}\text { Chronic conditions; } \\
\text { patients with } \\
\text { medication } \\
\text { management issues }\end{array}$ & $\begin{array}{l}\text { High risk patients } \\
\text { based on survey } \\
\text { conducted by PO or } \\
\text { provider }\end{array}$ & $\begin{array}{l}\text { Complex } \\
\text { chronic } \\
\text { disease, non- } \\
\text { compliant pa- } \\
\text { tients }\end{array}$ & $\begin{array}{l}\text { High utilizing } \\
\text { members }\end{array}$ \\
\hline $\begin{array}{l}\text { CMP history and } \\
\text { other information }\end{array}$ & $\begin{array}{l}\text { New. CM attends } \\
\text { PO learning } \\
\text { collaborative } \\
\text { meetings }\end{array}$ & $\begin{array}{l}\text { CMP in place prior to } \\
\text { pilot; CM functions in } \\
\text { quality improvement } \\
\text { role; CM has user } \\
\text { privileges in EHR }\end{array}$ & $\begin{array}{l}\text { CMP in place by } \\
\text { RN; panel member } \\
\text { works with } \\
\text { PharmD in team } \\
\text { approach }\end{array}$ & $\begin{array}{l}\text { New. CM attends } \\
\text { PO learning } \\
\text { collaborative } \\
\text { meetings }\end{array}$ & $\begin{array}{l}\text { CM in place } \\
\text { and highly } \\
\text { integrated }\end{array}$ & $\begin{array}{l}\text { Ongoing } \\
\text { disease } \\
\text { management } \\
\text { program }\end{array}$ \\
\hline
\end{tabular}

PDCM provider-delivered care management, HPDCM health plan-delivered care management, PO provider organization, CM care manager, CMP care management program PharmD doctor of pharmacy, $R N$ registered nurse, EHR electronic health records

$* P O-C$ and PO-D each had two sub-models. They are combined and described together

$\uparrow$ Size of practice: very small = single provider; small = two to three providers; medium $=$ four to ten providers; large $=11$ to 25 providers; very large $=$ more than 25 providers

t For PDCM programs, the centralized location is at the PO and the embedded location is at the practice; for HPDCM programs, the centralized location is at the health plan

$\S$ Programs differ in who initially offers the opportunity of care management to patients, and in what mode (in person or via phone) 
responsible to develop new, or expand existing, care management programs within their local context. However, both PDCM and HPDCM included a dedicated care manager and care management activities (i.e., chronic disease education, self-management support, motivational interviewing, goal setting, and health coaching). The PDCM programs varied from both HPDCM and each other in their targeting strategy, structure, program features and scope. ${ }^{22}$ Details of PO-specific approaches are shown in the first five columns in Table 1. Some key differences between PDCM programs were the mode of care management delivery (phone or in person), care manager background ( $\mathrm{RN}$ or PharmD), and the focus of care management efforts (patients with medication management issues or complex diseases).

\section{Study Design}

The need for ongoing program delivery prevented random assignment of POs and their associated members to PDCM or HPDCM. Thus, to compare the PDCM pilot (intervention) with the HPDCM program (comparison), we adopted a quasiexperimental two-group pre-post design. To create the comparison group, we selected patients belonging to primary care practices that either were not participating in the pilot, but were affiliated with one of the participating POs, or were similar to pilot practices in geographic area and size, but were affiliated with non-pilot POs. The first type shared the same central administrative support from the pilot POs and the second type was in close proximity with the pilot practices, which made both somewhat comparable to intervention practices. The pre-post periods covered 12 months before and after the pilot start and end dates.

\section{Study Populations}

Both groups included patients who were health plan members eligible for coverage with HPDCM and confirmed as having at least one of the five chronic diseases covered in HPDCM. PDCM included patients assigned to a PCP in one of the PDCM pilot practices and reported by the pilot POs as having received an attempted or actual contact for outreach by the pilot practice. HPDCM patients were assigned to a PCP in one of the selected comparison practices, identified as meeting health plan high-cost risk criteria (per claims-based algorithms), and outreached or had an outreach attempt by a health plan-employed nurse for HPDCM.

\section{Data Collection}

Care Management Processes. On a monthly basis, POs reported care management activities to the health plan, including 1) the number of patients "accepted" into the pilot, i.e., those confirmed by the practice as its patient and having one of more of the five chronic diseases; 2) patients "targeted" for the pilot, i.e., those outreached/offered care management; and 3) patients "engaged" in the pilot, i.e., those with one or more care management sessions/encounters with the care manager. For HPDCM, outreach and engagement status were obtained from nurse-recorded data in the health plan's information system.

Practice Characteristics. We obtained data from the health plan for several practice characteristics (Table 2), including the risk score of attributed patients. The average risk score (standardized to have a mean of one) is a claims-derived risk score for high health care costs (Ingenix Impact Intelligence ${ }^{\mathrm{TM}}$ ). As an indicator of practices' level of PCMH implementation, which would likely influence their ability to provide care management and other population-based health services, we obtained the 2009 PCMH scores collected by the health plan in conjunction with the plan's PCMH designation program. ${ }^{24}$

Patient Clinical Data. Because POs had different electronic health record (EHR) and registry systems, we constructed a data collection form so that each PO could query their data system using a common metric (e.g., ICD-9 diagnosis codes for the five diseases). Data extracted included age, sex, height, weight, body mass index (BMI), systolic and diastolic blood pressure (SBP and DBP), total cholesterol, high- and lowdensity lipoprotein (HDL and LDL), hemoglobin A1c $\left(\mathrm{HbA}_{1 \mathrm{c}}\right)$, B-type natriuretic peptide blood test, left ventricular ejection fraction, dates of diagnoses for any of the five chronic diseases above, and medications prescribed. All data spanned 1 April 2009 to 31 December 2012 (one year before, during and nearly one year after the pilot).

\section{Statistical Methods}

The primary outcomes were the proportions of patients with $\mathrm{LDL}<100 \mathrm{mg} / \mathrm{dL}, \mathrm{HDL} \geq 40 \mathrm{mg} / \mathrm{dL}$ (male) or $\mathrm{HDL} \geq 50 \mathrm{mg} /$ $\mathrm{dL}$ (female), total cholesterol $\leq 200 \mathrm{mg} / \mathrm{dL}, \mathrm{SBP}<140 \mathrm{mmHg}$ and $\mathrm{DBP}<80 \mathrm{mmHg}$, obesity (BMI $\geq 30$ ), extreme obesity $(\mathrm{BMI} \geq 40)$, and the average weight loss ( $\mathrm{kg})$, as these measures are commonly used by health plans for quality improvement. For patients with type 2 diabetes, following the American Diabetes Association guidelines, we defined an indicator for optimal outcome if the patient met these criteria: $\mathrm{HbA}_{1} \mathrm{c}<$ $7 \%$, SBP $<140 \mathrm{mmHg}$, DBP $<90 \mathrm{mmHg}$, and $\mathrm{LDL}<$ $100 \mathrm{mg} / \mathrm{dL} .^{25}$ B-type natriuretic peptide blood test and left ventricular ejection fraction had too few observations for meaningful analysis.

Consistent with the quasi-experimental two-group pre-post design, we used the difference-in-differences (DID) method to ameliorate potential selection bias (Fig. 1). The dashed line indicates the counterfactual outcome in the treatment group had there been no treatment. Thus, using the DID model, we subtracted differences in outcomes between PDCM and HPDCM prior to the interventions, i.e., the systematic differences, from the difference in outcomes between PDCM and HPDCM after the interventions to derive the comparative effectiveness. Hence, the baseline differences were not attributed to the programs. Due to difficulties in collecting EHR 
Table 2. Practice- and Patient-level Characteristics Between PDCM and HPDCM Groups

\begin{tabular}{|c|c|c|c|c|}
\hline & $\begin{array}{l}\text { Pilot PO } \\
\text { PDCM (1) }\end{array}$ & $\begin{array}{l}\text { Pilot PO } \\
\text { HPDCM (2) }\end{array}$ & $\begin{array}{l}\text { Non-pilot PO } \\
\text { HPDCM (3) }\end{array}$ & $\begin{array}{l}\text { Pilot PO and non-pilot PO } \\
\text { HPDCM (2) + (3) }\end{array}$ \\
\hline Number of practices in the study & 31 & 49 & 85 & 134 \\
\hline Practice-level characteristics & Mean (SD) & Mean (SD) & Mean (SD) & Mean (SD) \\
\hline Average Number of PCPs & $6.77(5.10)$ & $3.96(3.51)^{*}$ & $2.98(2.40)^{*}$ & $3.34(2.88)^{*}$ \\
\hline Average Number of adult members & $1310(775)$ & $714(428)^{*}$ & $900(916)^{*}$ & $832(778)^{*}$ \\
\hline $\begin{array}{l}\text { attributed to PCPs } \\
\text { Years since medical school graduation }\end{array}$ & $19.72(5.15)$ & $25.76(8.20)^{*}$ & $23.23(7.93)^{*}$ & $24.16(8.09)^{*}$ \\
\hline Average age for members attributed to PCPs & $45.00(2.49)$ & $45.24(3.12)$ & $44.31(6.83)$ & $44.65(5.76)$ \\
\hline Average risk score for members attributed to & $1.76(0.26)$ & $1.75(0.28)$ & $1.86(0.45)$ & $1.82(0.40)$ \\
\hline \multicolumn{5}{|l|}{ PCPs } \\
\hline Mean PCMH score & $0.46(0.11)$ & $0.42(0.15)$ & $0.37(0.19)^{*}$ & $0.39(0.18)$ \\
\hline N (\%) PCMH designation in 2009 & $29(93.55)$ & $29(59.18)^{*}$ & $18(21.18)^{*}$ & $47(35.07)^{*}$ \\
\hline $\begin{array}{l}\text { Total Number of patients with an outreached } \\
\text { date and clinical data }\end{array}$ & 2,363 & 767 & 870 & 1,637 \\
\hline \multicolumn{5}{|l|}{ Patient-level characteristics } \\
\hline Age, mean (SD) & $53.27(10.36)$ & $54.14(10.35)^{*}$ & $53.84(10.36)$ & $53.98(10.36)^{*}$ \\
\hline Number of chronic diseases (SD) & $1.26(0.55)$ & $1.24(0.54)$ & $1.17(0.44)^{*}$ & $1.20(0.49)^{*}$ \\
\hline N (\%) Male & $1158(49.05)$ & $379(49.41)$ & $486(55.86)^{*}$ & $865(52.84)^{*}$ \\
\hline N (\%) Diabetes & $1571(66.48)$ & $540(70.40)^{*}$ & $569(65.40)$ & $1109(67.75)$ \\
\hline N (\%) Asthma & $739(31.27)$ & $157(20.47)^{*}$ & $249(28.62)$ & $406(24.80)^{*}$ \\
\hline N (\%) Heart Failure & $138(5.84)$ & $39(5.08)$ & $25(2.87)^{*}$ & $64(3.91)^{*}$ \\
\hline $\mathrm{N}(\%)$ COPD & $94(3.98)$ & $63(8.21)^{*}$ & $37(4.25)$ & $100(6.11)^{*}$ \\
\hline $\mathrm{N}(\%) \mathrm{CHD}$ & $443(18.75)$ & $152(19.82)$ & $137(15.75)^{*}$ & $289(17.65)$ \\
\hline $\begin{array}{l}\text { Number of patients with an engagement date } \\
\text { and clinical data }\end{array}$ & 992 & 77 & 66 & 143 \\
\hline Age, mean (SD) & $53.80(9.46)$ & $54.74(9.80)$ & $55.77(9.44)^{*}$ & $55.22(9.62)^{*}$ \\
\hline Number of chronic diseases (SD) & $1.29(0.56)$ & $1.17(0.38)^{*}$ & $1.24(0.56)^{*}$ & $1.21(0.47)^{*}$ \\
\hline N (\%) Male & $488(49.24)$ & $39(50.65)$ & $38(57.58)^{*}$ & $77(53.85)$ \\
\hline N (\%) Diabetes & $676(68.15)$ & $59(76.62)^{*}$ & $43(65.15)$ & $102(71.33)$ \\
\hline N (\%) Asthma & $288(29.03)$ & $13(16.88)^{*}$ & $19(28.79)$ & $32(22.38)$ \\
\hline N (\%) Heart Failure & $58(5.85)$ & 0 & $3(4.55)$ & $3(2.10)^{*}$ \\
\hline $\mathrm{N}(\%)$ COPD & $53(5.34)$ & $4(5.19)^{*}$ & $7(10.61)$ & $11(7.69)$ \\
\hline $\mathrm{N}(\%) \mathrm{CHD}$ & $200(20.16)$ & $14(18.18)^{*}$ & $10(15.15)^{*}$ & $24(16.78)^{*}$ \\
\hline
\end{tabular}

PDCM provider-delivered care management, HPDCM health plan-delivered care management, PCMH patient centered medical home, POphysician organization, PCP primary care physician, COPD chronic obstructive pulmonary disease, CHD coronary heart disease

* indicates statistically significant difference from the pilot PO PDCM group (t-test for continuous variables and chi-square test for categorical variables)

data from non-pilot POs and the limited number of potential comparison patients, we could not use propensity score or other matching methods to select patients. However, matching and regression adjustment both controlled for observable confounders. $^{26,27}$

We employed generalized linear models, controlling patient and practice characteristics and accounting for the clustering of patients in practices and practices in POs. Each model included the main effect terms for PDCM, the pre-post indicator, and the interaction between them. The interaction term gave the DID estimate indicating whether PDCM led to more improvement in patient outcomes compared to HPDCM. We estimated the marginal predictions over the entire study population to estimate the causal average mean difference in changes in the outcomes. The $95 \%$ confidence intervals for all effect measures were based on percentiles via 1000 bootstrap replications using practice as the bootstrapping unit to account for clustering. ${ }^{28}$

We carried out the analyses first among patients who had been outreached (including those engaged) and then among only patients who had been engaged, because the act of outreaching to patients might have an effect on clinical outcomes, as facilitation of patient involvement in care has been found to be related to general adherence patterns. ${ }^{29}$ For "outreach," we used the first date of outreach as the start date; and for "engagement," we used the date of the first care management encounter as the start date.

\section{RESULTS}

The five POs selected 52 affiliated primary care practices to participate in the PDCM pilot. One practice changed its PO affiliation within the first year and was excluded from our study. One PO with 20 small practices could only produce meaningful data for ten patients, and was also excluded from analyses. Figure 2 summarizes the flow of the number of patients/practices in the remaining 31 PDCM practices and the combined HPDCM comparison group. The largest drop in sample size in the PDCM group was due to the inability of POs to confirm a chronic disease identified by the plan. The largest drop in sample size in the HPDCM group was due to a number of patients who were attributed by the health insurer to a specific PO, but were not found in the POs' EHRs. Among patients with at least one chronic disease documented in the EHRs, $87 \%$ of the PDCM and $76 \%$ of the HPDCM patients had some valid outcomes data for analyses. A total of 4,000 patients were clustered in 165 practices (31 in PDCM and 134 in HPDCM). 


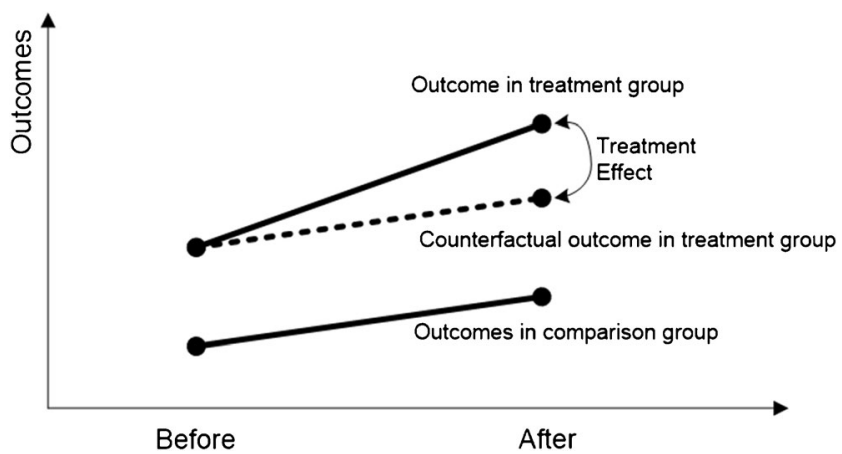

Figure 1. Causal effects in the difference-in-differences model.

Table 2 summarizes the practice-level and patient-level characteristics in PDCM and the two types of comparison groups. Compared to the HPDCM group, the PDCM group had a higher number of PCPs, higher number of adult patients attributed to PCPs, fewer average years since medical school graduation among PCPs, and higher proportion of practices with $\mathrm{PCMH}$ designation in the year before the pilot intervention, likely due to the PO's purposeful selection of highperforming practices to participate in the pilot. Generally, the PDCM patients were slightly younger, had higher number of chronic diseases, lower proportions of male patients, and higher proportions of patients with asthma and heart failure. In the following analyses, we adjusted for these significant differences.

Whether we used the first type of HPDCM group $(n=767)$ or the second type $(n=870)$ as comparison in the DID analyses, the results were similar. Thus, to improve efficiency, we combined the two groups together as one comparison group for the final results.

Among all outreached patients with at least one chronic disease (Table 3), the proportion of patients with $\mathrm{LDL}<$ $100 \mathrm{mg} / \mathrm{dL}$ increased by $3 \%$ for the PDCM group ( $95 \% \mathrm{CI}$ : $1 \%$ to $6 \%$ ) and $1 \%$ for the HPDCM group ( $95 \%$ CI: $-2 \%$ to
$5 \%$ ). However, the difference in these improvements, i.e., the DID estimate of $2 \%$, was not statistically significant ( $95 \% \mathrm{CI}$ : $-2 \%$ to $6 \%$ ). Among all HPDCM patients, effects of engagement were generally larger than effects of outreach; in the PDCM group, however, no effect was statistically significant among engaged patients.

Among outreached diabetic patients (Table 4), the proportion of PDCM patients with $\mathrm{LDL}<100 \mathrm{mg} / \mathrm{dL}$ increased by $4 \%$ (95\% CI: $1 \%$ to $7 \%$ ). For the HPDCM, there was a significant improvement in the proportion of patients with optimal outcomes after outreach as compared to before (3\%, $95 \%$ CI: $2 \%$ to $6 \%$ ). There was a significant difference in the proportion of obesity between the two groups $(4 \%, 95 \% \mathrm{CI}$ : $0.3 \%$ to $8 \%$ ) favoring HPDCM. Among engaged diabetic patients, the proportion of HPDCM patients with LDL $<$ $100 \mathrm{mg} / \mathrm{dL}$ increased by $12 \%$ (95\% CI: $0.1 \%$ to $23 \%$ ). Again, effects among engaged patients were generally larger in the HPDCM group. However, the DID estimates were not statistically significant for any outcomes in engaged patients.

\section{DISCUSSION}

In this comparison of PDCM to HPDCM, we found that neither care management delivery mode had clear advantages over the other during the first year of follow-up, in terms of $\mathrm{HbA}_{1 \mathrm{c}}$, blood pressure, LDL, and weight loss. In fact, there was minimal evidence of effectiveness of either program for these outcomes. The minor improvement in cholesterol (three more patients out of 100 achieving $\mathrm{LDL}<100 \mathrm{mg} / \mathrm{dL}$ ) in the short term might not be significant at the population level, but it is consistent with, if not more significant than, the recent trend. ${ }^{30}$ Our lack of significant findings may be related to several factors. First, only about $30 \%$ of the study population was older than 60 years, representing a somewhat younger, chronically ill adult population. The majority of the study
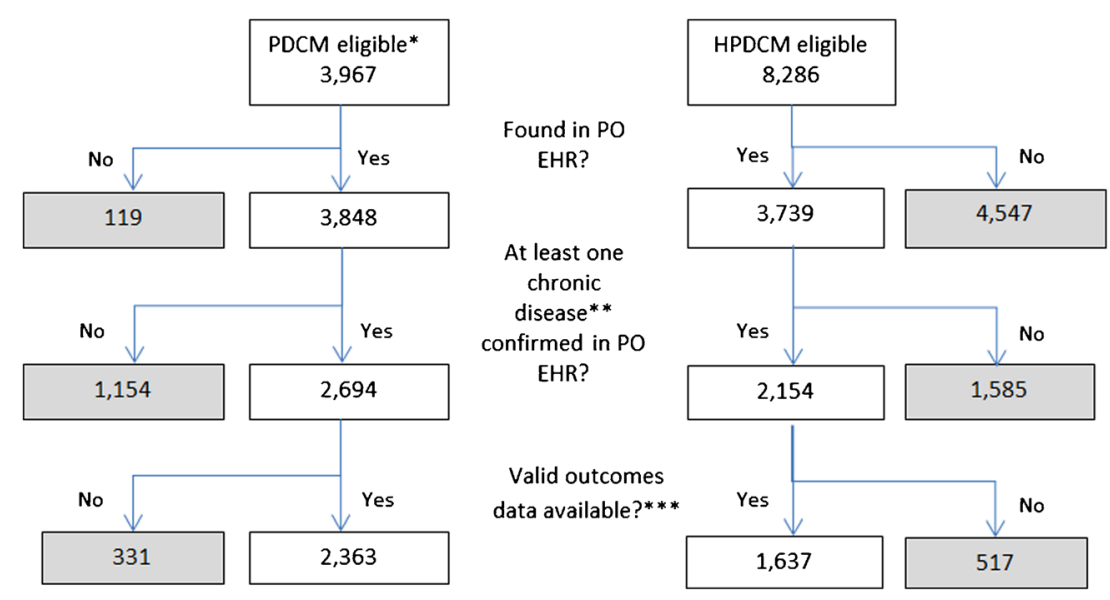

Figure 2. Flow diagram of study population. * Eligibility based on HPDCM's criteria (identified by the health plan via administrative data as having at least one of five chronic diseases, and having coverage for HPDCM), and having been accepted by the PO into the pilot. POs had different selection criteria for outreaching to patients. One pilot PO was excluded due to lack of EHR data. ** Five chronic diseases were included in the pilot: congestive heart failure, chronic obstructive pulmonary disease, coronary heart disease, diabetes, and asthma. *** Some patients were found in PO's EHR, but they did not have the primary outcome data for this study. 
Table 3. Clinical Outcomes for Patients with at Least One Chronic Disease in PDCM and HPDCM Groups

\begin{tabular}{|c|c|c|c|c|c|c|c|c|}
\hline \multirow[t]{2}{*}{ Outreached $^{*}$} & \multirow{2}{*}{$\begin{array}{l}\text { Number of } \\
\text { measurements } \\
\text { (individuals) }\end{array}$} & \multicolumn{3}{|l|}{ PDCM } & \multicolumn{3}{|c|}{ HPDCM } & \multirow{2}{*}{$\begin{array}{l}\text { Difference in } \\
\text { Differences } \\
\text { [(B)-(A)] } \\
-[(D)-(C)](95 \% \\
\text { CI })\end{array}$} \\
\hline & & $\begin{array}{l}12- \\
\text { month } \\
\text { Before } \\
\text { (A) }\end{array}$ & $\begin{array}{l}\text { 12- } \\
\text { month } \\
\text { After } \\
\text { (B) }\end{array}$ & $\begin{array}{l}\text { Difference } \\
\text { (B)-(A) }(95 \\
\% \text { CI) }\end{array}$ & $\begin{array}{l}12- \\
\text { month } \\
\text { Before } \\
\text { (C) }\end{array}$ & $\begin{array}{l}\text { 12- } \\
\text { month } \\
\text { After } \\
\text { (D) }\end{array}$ & $\begin{array}{l}\text { Difference } \\
\text { (D)-(C) }(95 \\
\% \text { CI) }\end{array}$ & \\
\hline $\begin{array}{l}\text { Prop. SBP }<140 \\
\mathrm{mmHg} \& \mathrm{DBP}< \\
80 \mathrm{mmHg}\end{array}$ & $\begin{array}{l}17,193 \\
(3,483)\end{array}$ & 0.59 & 0.61 & $\begin{array}{l}0.02 \\
(-0.01,0.05)\end{array}$ & 0.48 & 0.50 & $\begin{array}{l}0.02 \\
(-0.01,0.04)\end{array}$ & $\begin{array}{l}0.002 \\
(-0.04,0.04)\end{array}$ \\
\hline $\begin{array}{l}\text { Prop. LDL < } 100 \\
\text { mg/dL }\end{array}$ & $\begin{array}{l}9,279 \\
(3,414)\end{array}$ & 0.57 & 0.59 & \multirow{2}{*}{$\begin{array}{l}\mathbf{0 . 0 3} \\
\mathbf{( 0 . 0 1 ,} \mathbf{0 . 0 6}) \\
0.002 \\
(-0.02,0.03)\end{array}$} & 0.55 & 0.56 & $\begin{array}{l}0.01 \\
(-0.02,0.05)\end{array}$ & $\begin{array}{l}0.02 \\
(-0.02,0.06)\end{array}$ \\
\hline $\begin{array}{l}\text { Prop.HDL } \geq 40 \\
\mathrm{mg} / \mathrm{dL} \text { (male) and } \\
50 \mathrm{mg} / \mathrm{dL}(\mathrm{female})\end{array}$ & $\begin{array}{l}9,225 \\
(3,395)\end{array}$ & 0.42 & 0.42 & & 0.48 & 0.51 & $\begin{array}{l}0.04 \\
(-0.01,0.06)\end{array}$ & $\begin{array}{l}-0.03 \\
(-0.07,0.004)\end{array}$ \\
\hline $\begin{array}{l}\text { Prop. total } \\
\text { cholesterol } \leq 200 \\
\mathrm{mg} / \mathrm{dL}\end{array}$ & $\begin{array}{l}8,639 \\
(3,401)\end{array}$ & 0.75 & 0.77 & \multirow{4}{*}{$\begin{array}{l}0.02 \\
(-0.003, \\
0.04) \\
0.44 \\
(-0.58,1.30) \\
0.02 \\
(-0.003, \\
0.03) \\
0.02 \\
(0.004,0.04)\end{array}$} & 0.73 & 0.74 & $\begin{array}{l}0.02 \\
(-0.01,0.05)\end{array}$ & $\begin{array}{l}0.001 \\
(-0.03,0.04)\end{array}$ \\
\hline $\begin{array}{l}\text { Mean Weight in } \\
\mathrm{kg}\end{array}$ & $\begin{array}{l}16,860 \\
(3,454)\end{array}$ & 98.6 & 99.1 & & 99.9 & 99.4 & $\begin{array}{l}-0.56 \\
(-1.98,0.65)\end{array}$ & $\begin{array}{l}1.00 \\
(-0.57,2.54)\end{array}$ \\
\hline Prop. obese & $\begin{array}{l}13,920 \\
(3,282)\end{array}$ & 0.66 & 0.68 & & 0.65 & 0.63 & $\begin{array}{l}-0.01 \\
(-0.04,0.01)\end{array}$ & $\begin{array}{l}0.03 \\
(-0.004,0.06)\end{array}$ \\
\hline $\begin{array}{l}\text { Prop. extreme } \\
\text { obese } \\
\text { Engaged }^{\dagger}\end{array}$ & $\begin{array}{l}13,920 \\
(3,282)\end{array}$ & 0.18 & 0.20 & & 0.20 & 0.20 & $\begin{array}{l}0.01 \\
(-0.02,0.03)\end{array}$ & $\begin{array}{l}0.02 \\
(-0.01,0.05)\end{array}$ \\
\hline $\begin{array}{l}\text { Prop. SBP }< \\
140 \mathrm{mmHg} \& \\
\text { DBP }<80 \mathrm{mmHg}\end{array}$ & $\begin{array}{l}5,208 \\
(1,076)\end{array}$ & 0.59 & 0.60 & $\begin{array}{l}0.01 \\
(-0.04,0.05)\end{array}$ & 0.47 & 0.53 & $\begin{array}{l}0.06 \\
(0.001,0.14)\end{array}$ & $\begin{array}{l}-0.05 \\
(-0.14,0.02)\end{array}$ \\
\hline $\begin{array}{l}\text { Prop. LDL < } \\
100 \mathrm{mg} / \mathrm{dL}\end{array}$ & $\begin{array}{l}2,805 \\
(1,016)\end{array}$ & 0.60 & 0.63 & $\begin{array}{l}0.03 \\
(-0.01,0.08)\end{array}$ & 0.48 & 0.56 & $\begin{array}{l}0.08 \\
(-0.03,0.19)\end{array}$ & $\begin{array}{l}-0.05 \\
(-0.17,0.08)\end{array}$ \\
\hline $\begin{array}{l}\text { Prop.HDL } \geq 40 \\
\mathrm{mg} / \mathrm{dL} \text { (male) and } \\
50 \mathrm{mg} / \mathrm{dL} \text { (female) }\end{array}$ & $\begin{array}{l}2,772 \\
(1,001)\end{array}$ & 0.40 & 0.37 & $\begin{array}{l}-0.04 \\
(-0.02,0.06)\end{array}$ & 0.42 & 0.49 & $\begin{array}{l}0.07 \\
(-0.03,0.17)\end{array}$ & $\begin{array}{l}-0.11 \\
(-0.14,0.04)\end{array}$ \\
\hline $\begin{array}{l}\text { Prop. total } \\
\text { cholesterol } \leq 200 \\
\mathrm{mg} / \mathrm{dL}\end{array}$ & $\begin{array}{l}2,695 \\
(1,002)\end{array}$ & 0.76 & 0.77 & $\begin{array}{l}0.01 \\
(-0.003 \\
0.04)\end{array}$ & 0.77 & 0.84 & $\begin{array}{l}0.07 \\
(-0.01,0.15)\end{array}$ & $\begin{array}{l}-0.05 \\
(-0.03,0.04)\end{array}$ \\
\hline $\begin{array}{l}\text { Mean Weight in } \\
\mathrm{kg}\end{array}$ & $\begin{array}{l}5,151 \\
(1,074)\end{array}$ & 102.1 & 102.8 & $\begin{array}{l}0.70 \\
(-1.21,2.36)\end{array}$ & 111.5 & 108.6 & $\begin{array}{l}-2.93 \\
(-7.06,1.03)\end{array}$ & $\begin{array}{l}3.64 \\
(-0.85,8.03)\end{array}$ \\
\hline Prop. obese & $\begin{array}{l}4,264 \\
(1,038)\end{array}$ & 0.75 & 0.75 & $\begin{array}{l}-0.001 \\
(-0.03,0.02)\end{array}$ & 0.70 & 0.71 & $\begin{array}{l}0.02 \\
(-0.07,0.09)\end{array}$ & $\begin{array}{l}-0.02 \\
(-0.09,0.07)\end{array}$ \\
\hline $\begin{array}{l}\text { Prop. extreme } \\
\text { obese }\end{array}$ & $\begin{array}{l}4,264 \\
(1,038)\end{array}$ & 0.25 & 0.26 & $\begin{array}{l}0.003 \\
(-0.04,0.03)\end{array}$ & 0.30 & 0.33 & $\begin{array}{l}0.03 \\
(-0.05,0.10)\end{array}$ & $\begin{array}{l}-0.03 \\
(-0.10,0.06)\end{array}$ \\
\hline
\end{tabular}

Bootstrap confidence intervals based on percentiles in 1000 replications are in parentheses; adjusted for practice-and patient-level factors that differed significantly at baseline (see Table 2). PDCM provider-delivered care management, HPDCM health plan-delivered care management, SBP systolic blood pressure, DBP diastolic blood pressure, LDL low-density lipoprotein, HDL high-density lipoprotein, Prop. proportion

* Outreached patients were those who received an attempted or actual contact for enrollment in care management

tEngaged patients were those who had one or more care management sessions/encounters with a care manager

patients might not have needed intensive care management, with about half of them already meeting SBP, DBP and LDL criteria at baseline. Second, improvements in clinical outcomes can take long periods of time, and 12 months post-care management may not have been a sufficient amount of time to detect measureable changes. In a systematic review, Norris and colleagues $^{31}$ found many studies documented improvements within 12 months of the launch of care management, although longer studies did show larger effects. We did not have access to other intermediate outcomes, such as changes in patient behaviors, which may have improved despite no appreciable clinical improvement. Third, we relied on data from different EHRs and registries, which had varying degrees of data quality. Fourth, PDCM pilot practices appeared to have a slightly higher proportion of patients meeting recommended guidelines prior to the intervention than HPDCM practices. Thus, for some outcomes, PDCM patients had less room to improve than HPDCM patients. Fifth, we analyzed our data based on the intent-to-treat principle in clinical trials. In real world studies, because of diverse patient populations, not all patients were targeted for all outcomes. However, we had limited information on the specific contents and goals of care management for individual patients, which precluded the possibility for subgroup analyses based on specific targets. Sixth, we defined engagement as having at least one care management encounter. Since we did not measure the "dose" of care management received by patients, we could not carry out a sensitivity analysis for different definitions of engagement. Finally, these data were collected from specific POs in Michigan, limiting the generalizability to other settings.

We did not collect data on costs of running the programs; thus, a full cost-effectiveness analysis could not be carried out. However, even though there were not many significant differences in effectiveness between the two groups in the short term, there was a significant cost saving in healthcare expenditure, including out of pocket spending after 2.5 years among PDCM patients. ${ }^{23}$ 
Table 4. Clinical Outcomes for Diabetic Patients in PDCM and HPDCM Groups

\begin{tabular}{|c|c|c|c|c|c|c|c|c|}
\hline \multirow[t]{2}{*}{ Outreached $^{*}$} & \multirow{2}{*}{$\begin{array}{l}\text { Number of } \\
\text { measurements } \\
\text { (individuals) }\end{array}$} & \multicolumn{3}{|l|}{ PDCM } & \multicolumn{3}{|c|}{ HPDCM } & \multirow{2}{*}{$\begin{array}{l}\text { Difference in } \\
\text { Differences } \\
{[(B)-(A)]} \\
-[(D)-(C)](95 \% \\
\text { CI })\end{array}$} \\
\hline & & $\begin{array}{l}\text { 12- } \\
\text { month } \\
\text { Before } \\
\text { (A) }\end{array}$ & $\begin{array}{l}\text { 12- } \\
\text { month } \\
\text { After } \\
\text { (B) }\end{array}$ & $\begin{array}{l}\text { Difference } \\
\text { (B)-(A) }(95 \\
\% \text { CI })\end{array}$ & $\begin{array}{l}\text { 12- } \\
\text { month } \\
\text { Before } \\
\text { (C) }\end{array}$ & $\begin{array}{l}\text { 12- } \\
\text { month } \\
\text { After } \\
\text { (D) }\end{array}$ & $\begin{array}{l}\text { Difference } \\
\text { (D)-(C) }(95 \\
\% \text { CI })\end{array}$ & \\
\hline Prop. A1c $<7 \%$ & $\begin{array}{l}8,036 \\
(2,312)\end{array}$ & 0.47 & 0.46 & $\begin{array}{l}-0.01 \\
(-0.04,0.02)\end{array}$ & 0.43 & 0.43 & $\begin{array}{l}0.003 \\
(-0.03,0.04)\end{array}$ & $\begin{array}{l}-0.01 \\
(-0.06,0.03)\end{array}$ \\
\hline $\begin{array}{l}\text { Prop.Optimal } \\
\text { outcome }^{\S}\end{array}$ & $\begin{array}{l}3,742 \\
(1,472)\end{array}$ & 0.14 & 0.18 & $\begin{array}{l}0.04 \\
(-0.002 \\
0.09)\end{array}$ & 0.09 & 0.12 & $\begin{array}{l}0.03 \\
(0.02,0.06)\end{array}$ & $\begin{array}{l}0.01 \\
(-0.04,0.06)\end{array}$ \\
\hline $\begin{array}{l}\text { Prop. SBP }<140 \\
\mathrm{mmHg} \& \mathrm{DBP}< \\
80 \mathrm{mmHg}\end{array}$ & $\begin{array}{l}11,982 \\
(2,332)\end{array}$ & 0.60 & 0.61 & $\begin{array}{l}0.01 \\
(-0.02,0.04)\end{array}$ & 0.44 & 0.47 & $\begin{array}{l}0.03 \\
(-0.001,0.06)\end{array}$ & $\begin{array}{l}-0.02 \\
(-0.06,0.02)\end{array}$ \\
\hline $\begin{array}{l}\text { Prop. LDL }<100 \\
\mathrm{mg} / \mathrm{dL}\end{array}$ & $\begin{array}{l}7,277 \\
(2,477)\end{array}$ & 0.61 & 0.65 & $\begin{array}{l}0.04 \\
(0.01,0.07)\end{array}$ & 0.57 & 0.59 & $\begin{array}{l}0.02 \\
(-0.01,0.06)\end{array}$ & $\begin{array}{l}0.02 \\
(-0.03,0.06)\end{array}$ \\
\hline $\begin{array}{l}\text { Prop.HDL } \geq 40 \\
\mathrm{mg} / \mathrm{dL} \text { (male) and } \\
50 \mathrm{mg} / \mathrm{dL} \text { (female) }\end{array}$ & $\begin{array}{l}7,164 \\
(2,455)\end{array}$ & 0.39 & 0.39 & $\begin{array}{l}-0.005 \\
(-0.03,0.03)\end{array}$ & 0.44 & 0.48 & $\begin{array}{l}0.04 \\
(0.01,0.07)\end{array}$ & $\begin{array}{l}-0.04 \\
(-0.03,0.03)\end{array}$ \\
\hline $\begin{array}{l}\text { Prop. total } \\
\text { cholesterol } \leq 200 \\
\text { mg/dL }\end{array}$ & $\begin{array}{l}6,506 \\
(2,452)\end{array}$ & 0.79 & 0.80 & $\begin{array}{l}0.01 \\
(-0.02,0.03)\end{array}$ & 0.74 & 0.77 & $\begin{array}{l}0.03 \\
(-0.01,0.06)\end{array}$ & $\begin{array}{l}-0.02 \\
(-0.06,0.02)\end{array}$ \\
\hline Mean Weight in $\mathrm{kg}$ & $\begin{array}{l}11,809 \\
(2,310)\end{array}$ & 101.2 & 102.1 & $\begin{array}{l}0.87 \\
(-0.46,1.89)\end{array}$ & 103.8 & 102.9 & $\begin{array}{l}-0.84 \\
(-2.22,0.43)\end{array}$ & $\begin{array}{l}1.71 \\
(-0.68,3.48)\end{array}$ \\
\hline Prop. obese & $\begin{array}{l}9,493 \\
(2,177)\end{array}$ & 0.71 & 0.72 & $\begin{array}{l}0.02 \\
(-0.01,0.04)\end{array}$ & 0.75 & 0.72 & $\begin{array}{l}-0.03 \\
(-0.06 \\
-0.003)\end{array}$ & $\begin{array}{l}0.04 \\
(0.003,0.08)\end{array}$ \\
\hline $\begin{array}{l}\text { Prop. extreme } \\
\text { obese } \\
\text { Engaged }^{\dagger}\end{array}$ & $\begin{array}{l}9,493 \\
(2,177)\end{array}$ & 0.21 & 0.23 & $\begin{array}{l}0.03 \\
(0.004,0.05)\end{array}$ & 0.24 & 0.25 & $\begin{array}{l}0.01 \\
(-0.03,0.04)\end{array}$ & $\begin{array}{l}0.02 \\
(-0.02,0.06)\end{array}$ \\
\hline Prop. A1c $<7 \%$ & $\begin{array}{l}2,792 \\
(706)\end{array}$ & 0.42 & 0.42 & $\begin{array}{l}0.003 \\
(-0.03,0.04)\end{array}$ & 0.43 & 0.47 & $\begin{array}{l}0.04 \\
(-0.04,0.12)\end{array}$ & $\begin{array}{l}-0.04 \\
(-0.12,0.06)\end{array}$ \\
\hline $\begin{array}{l}\text { Prop.Optimal } \\
\text { outcome }^{+}\end{array}$ & $\begin{array}{l}1,225 \\
(498)\end{array}$ & 0.16 & 0.16 & $\begin{array}{l}0.004 \\
(-0.05,0.08)\end{array}$ & 0.07 & 0.17 & $\begin{array}{l}0.10 \\
(-0.01,0.18)\end{array}$ & $\begin{array}{l}-0.09 \\
(-0.19,0.05)\end{array}$ \\
\hline $\begin{array}{l}\text { Prop. } \mathrm{SBP}<140 \\
\mathrm{mmHg} \& \mathrm{DBP}< \\
80\end{array}$ & $\begin{array}{l}3,879 \\
(738)\end{array}$ & 0.59 & 0.59 & $\begin{array}{l}0.001 \\
(-0.05,0.05)\end{array}$ & 0.44 & 0.51 & $\begin{array}{l}0.07 \\
(-0.01,0.16)\end{array}$ & $\begin{array}{l}-0.07 \\
(-0.17,0.02)\end{array}$ \\
\hline $\begin{array}{l}\text { Prop. LDL }< \\
100 \mathrm{mg} / \mathrm{dL}\end{array}$ & $\begin{array}{l}2,163 \\
(740)\end{array}$ & 0.64 & 0.67 & $\begin{array}{l}0.04 \\
(-0.01,0.08)\end{array}$ & 0.48 & 0.59 & $\begin{array}{l}0.12 \\
(0.001,0.23)\end{array}$ & $\begin{array}{l}-0.08 \\
(-0.21,0.05)\end{array}$ \\
\hline $\begin{array}{l}\text { Prop.HDL } \geq 40 \\
\mathrm{mg} / \mathrm{dL}(\text { male }) \text { and } \\
50 \mathrm{mg} / \mathrm{dL}(\text { female })\end{array}$ & $\begin{array}{l}2,213 \\
(726)\end{array}$ & 0.37 & 0.35 & $\begin{array}{l}-0.02 \\
(-0.05,0.02)\end{array}$ & 0.38 & 0.44 & $\begin{array}{l}0.06 \\
(-0.04,0.17)\end{array}$ & $\begin{array}{l}-0.09 \\
(-0.19,0.02)\end{array}$ \\
\hline $\begin{array}{l}\text { Prop. total } \\
\text { cholesterol } \leq 200 \\
\text { mg/dL }\end{array}$ & $\begin{array}{l}2,034 \\
(726)\end{array}$ & 0.78 & 0.81 & $\begin{array}{l}0.02 \\
(-0.01,0.06)\end{array}$ & 0.76 & 0.84 & $\begin{array}{l}0.08 \\
(-0.003,0.18)\end{array}$ & $\begin{array}{l}-0.06 \\
(-0.17,0.03)\end{array}$ \\
\hline $\begin{array}{l}\text { Mean Weight in } \\
\mathrm{kg}\end{array}$ & $\begin{array}{l}3,854 \\
(737)\end{array}$ & 104.9 & 106.1 & $\begin{array}{l}1.20 \\
(-0.91,3.02)\end{array}$ & 112.3 & 108.9 & $\begin{array}{l}-3.45 \\
(-8.82,0.72)\end{array}$ & $\begin{array}{l}4.65 \\
(-0.02,10.10)\end{array}$ \\
\hline Prop. obese & $\begin{array}{l}3,045 \\
(704)\end{array}$ & 0.79 & 0.79 & $\begin{array}{l}-0.002 \\
(-0.03,0.02)\end{array}$ & 0.82 & 0.76 & $\begin{array}{l}-0.05 \\
(-0.14,-0.03)\end{array}$ & $\begin{array}{l}0.05 \\
(-0.03,0.14)\end{array}$ \\
\hline $\begin{array}{l}\text { Prop. extreme } \\
\text { obese }\end{array}$ & $\begin{array}{l}3,045 \\
(704)\end{array}$ & 0.28 & 0.29 & $\begin{array}{l}0.01 \\
(-0.04,0.05)\end{array}$ & 0.36 & 0.34 & $\begin{array}{l}-0.02 \\
(-0.14,0.06)\end{array}$ & $\begin{array}{l}0.03 \\
(-0.07,0.14)\end{array}$ \\
\hline
\end{tabular}

See footnotes under Tables 2 and 3

* Outreached patients were those who received an attempted or actual contact for enrollment in care management

+ Engaged patients were those who had one or more care management sessions/encounters with a care manager

I Optimal outcome $=A 1 \mathrm{c}<7 \%, \mathrm{SBP}<140 \mathrm{mmHg}, \mathrm{DBP}<90 \mathrm{mmHg}$, and $\mathrm{LDL}<100 \mathrm{mg} / \mathrm{dL}$

An unexpected finding in the process of data collection was that among patients who met the health insurer's eligibility criteria and were found in POs' EHRs, quite a few patients ( $30 \%$ for PDCM and $42 \%$ for HPDCM) did not have a documented chronic disease in the EHRs. ${ }^{32}$ This suggested that many EHRs may not be ready for clinical research, ${ }^{33}$ or that the insurer's administrative data contained spurious diagnoses, ${ }^{34}$ or both. We also had to exclude patients who met the inclusion criteria and had a known start date for outreach, but did not have any clinical measures such as $\mathrm{HbA}_{1} \mathrm{c}$ or LDL. Compared to the patients included in our analyses, the excluded patients ( $n=331$ for PDCM and 517 for HPDCM) might be systematically different. Based on the health plan data alone, the excluded PDCM patients were slightly younger and had fewer chronic diseases than the included PDCM patients; and the excluded HPDCM patients had a lower prevalence of diabetes, but higher prevalence of asthma and COPD than the included HPDCM patients (data not shown). It is likely that, given the characteristics of the excluded patients, including them would not increase our chance of detecting significant effects. The discrepancy between health 
plan data versus practice EHR data tells a cautionary tale regarding studies using administrative data that are not research ready.

Practices in the pilot POs employed both objective criteria and subjective clinical judgment in selecting patients for outreach. Thus, the outreached patients in PDCM versus HPDCM were not as comparable as they would be in a randomized controlled trial. The DID approach we adopted relies on the assumption that the clinical outcome trends in the PDCM group would be the same as the trends in the HPDCM group, had the PDCM patients been exposed to the HPDCM intervention. This assumption might be violated if some unobserved causes led to different trends regardless of the intervention.

It would be ideal to compare our findings to similar studies in which a practice-based care management is compared to a health plan-delivered care management program. However, we were unable to locate any such published research. Existing literature typically finds positive clinical improvements comparing care management with usual care in carefully controlled settings, ${ }^{8-10,13}$ in contrast to this study's real world implementation. Research on factors related to successful implementation of care management that leads to clinical improvement is limited. When care management is embedded into the primary care practice, it will produce greater participation and improved clinical results as compared to usual care. ${ }^{5,11}$ Our qualitative work ${ }^{35}$ provides evidence that the PDCM approaches were highly variable across POs, likely with variable success. When averaged across all PDCM practices, the effects of specific strategies might have been masked or dampened

From an implementation standpoint, the more embedded the care manager, the greater the success in engaging patients in working with the care manager. Although we did not quantitatively examine other factors, our qualitative work strongly leads us to suspect that other factors significantly impacted clinical outcomes within the 1 -year time frame of this study. ${ }^{36}$ These other factors include the dose and effectiveness of the care management interventions by the care manager and the potential for improvement of the clinical targets and behavioral goals of those patients. Another significant factor is the degree of effective team functioning among practice members, especially noticeable when a care manager is embedded in the practice. Further exploration of these elements is definitely warranted to move the field forward.

In summary, our study suggests that while both health plan- and provider-delivered care management may demonstrate some minimal improvement in clinical values, when compared to each other using a DID approach, neither was found to be superior to the other. Since this comparison is unique in the literature, further research should explore potential differences in care management strategies that may account for program effect on specific outcomes.
Acknowledgements: We would like to thank Laurie Fitzpatrick for data collection; the physician organizations involved in the pilot: Henry Ford Health System, Genesys Medical Group, Lakeshore Health Network, Integrated Health Partners and the University of Michigan Health System for their participation; and Margaret Mason and Lisa Rajt of Blue Cross Blue Shield of Michigan for their leadership of the pilot.

Funding for this research was provided by the Agency for Healthcare Research and Quality, grant number 1R18 HS020108-01. We presented an earlier version of the manuscript as an oral presentation (Jodi S. Holtrop) at the North American Primary Care Research Group Annual Meeting in New York, in November 2014.

Corresponding Author: Zhehui Luo, MS, PhD; Department of Epidemiology and Biostatistics, College of Human MedicineMichigan State University, East Lansing, MI, USA (e-mail: zluo@msu.edu).

\section{Compliance with ethical standards:}

Conflicts of Interest: Gretchen Piatt received grants from Bristol Myers Squibb Foundation for unrelated work. Min Tao is an employee of Blue Cross and Blue Shield of Michigan. All other authors declare that they do not have a conflict of interest.

\section{REFERENCES}

1. Center for Health Care Strategies. Care management definition and framework. Available at: http://www.chcs.org/usr_doc/Care_Management_Framework.pdf. Accessed January 25, 2016.

2. Goetzel RZ, Ozminkowski RJ, Sederer LI, Mark TL. The business case for quality mental health services: why employers should care about the mental health and well-being of their employees. J Occup Environ Med. 2002;44(4):320-30.

3. Sochalski J, Jaarsma T, Krumholz HM, et al. What works in chronic care management: the case of heart failure. Health Aff (Millwood). 2009;28(1):179-89.

4. Egginton JS, Ridgeway JL, Shah ND, et al. Care management for type 2 diabetes in the United States: a systematic review and meta-analysis. BMC Health Serv Res. 2012;12:72.

5. Daaleman TP, Hay S, Prentice A, Gwynne MD. Embedding care management in the medical home: a case study. J Prim Care Commun Health. 2014;5(2):97-100.

6. Taliani CA, Bricker PL, Adelman AM, Cronholm PF, Gabbay RA Implementing effective care management in the patient-centered medical home. Am J Manag Care. 2013;19(12):957-64.

7. Hines P, Mercury M. Designing the role of the embedded care manager. Prof Case Manag. 2013;18(4): 182-7. quiz 188-9.

8. Dorr DA, Wilcox A, Burns L, Brunker CP, Narus SP, Clayton PD. Implementing a multidisease chronic care model in primary care using people and technology. Dis Manag. 2006;9(1):1-15.

9. Dorr DA, Wilcox A, Donnelly SM, Burns L, Clayton PD. Impact of generalist care managers on patients with diabetes. Health Serv Res. 2005;40(5 Pt 1):1400-21.

10. Boult C, Reider L, Frey K, et al. Early effects of "Guided Care" on the quality of health care for multimorbid older persons: a cluster-randomized controlled trial. J Gerontol A Biol Sci Med Sci. 2008;63(3):321-7.

11. Coleman K, Mattke S, Perrault PJ, Wagner EH. Untangling practice redesign from disease management: how do we best care for the chronically ill? Annu Rev Public Health. 2009;30:385-408.

12. Noel PH, Lanham HJ, Palmer RF, Leykum LK, Parchman ML. The importance of relational coordination and reciprocal learning for chronic illness care within primary care teams. Health Care Manag Rev. 2013;38(1):20-8.

13. Knight $\mathbf{K}$, Badamgarav E, Henning JM, et al. A systematic review of diabetes disease management programs. Am J Manag Care. 2005; 11(4):242-50.

14. Mattke S, Seid M, Ma S. Evidence for the effect of disease management: is \$1 billion a year a good investment? Am J Manag Care. 2007; 13(12):670-6.

15. Stellefson $\mathbf{M}$, Dipnarine $\mathbf{K}$, Stopka $\mathbf{C}$. The chronic care model and diabetes management in US primary care settings: a systematic review. Prev Chronic Dis. 2013;10, E26.

16. NHS Institute for Innovation and Improvement. Improving care for people with long-term conditions. Available at: http://www.improvingchroniccare. 
org/downloads/review_of_international_frameworks_chris_hamm.pdf. Accessed January 25, 2016.

17. Robert Graham Center for Policy Studies in Family Medicine and Primary Care. The patient centered medical home: history, seven core features, evidence and transformational change. Available at: http://www.grahamcenter.org/dam/rgc/documents/publications-reports/monographsbooks/rgcmo-medical-home.pdf. Accessed January 25, 2016.

18. Crabtree BF, Chase SM, Wise CG, et al. Evaluation of patient centered medical home practice transformation initiatives. Med Care. 2011;49(1):10-6.

19. Patient-Centered Primary Care Collaborative. Defining the medical home: a patient-centered philosophy that drives primary care excellence. Available at: http://www.pcpcc.org/about/medical-home. Accessed January 25, 2016.

20. Taylor EF, Machta RM, Meyers DS, Genevro J, Peikes DN. Enhancing the primary care team to provide redesigned care: the roles of practice facilitators and care managers. Ann Fam Med. 2013;11(1):80-3.

21. Peikes DN, Reid RJ, Day TJ, et al. Staffing patterns of primary care practices in the comprehensive primary care initiative. Ann Fam Med. 2014;12(2):142-9.

22. Annis AM, Holtrop JS, Tao M, Chang H-C, Luo Z. Comparison of provider- and plan-based targeting strategies for disease care management. Am J Manag Care. 2015;21(5):344-51.

23. Chang H-C, Chung H, Tao M, Luo, Z. Holtrop JS. A comparison of care management delivery models on the trajectories of medical costs among patients with chronic disease: four-year follow-up results. Health Services and Outcomes Research Methodology. under review.

24. Alexander JA, Paustian M, Wise CG, et al. Assessment and measurement of patient-centered medical home implementation: the BCBSM experience. Ann Fam Med. 2013;11(Suppl 1):S74-81.

25. American Diabetes Association. Standards of medical care in diabetes 2013. Diabetes Care. 2013;36(Supp 1):S11-60.

26. Stürmer T, Joshi M, Glynn RJ, Avorn J, Rothman KJ, Schneeweiss S. A review of the applications of propensity score methods yielded increasing use, advantages in specific settings, but not substantially different estimates compared with conventional multivariable methods. J Clin Epidemiol. 2006;59:437-47.

27. Luo Z, Gardiner JC, Bradley CJ. Applying propensity score methods in medical research: pitfalls and prospects. Med Care Res Rev. 2010;67(5):528-54.

28. Efron B, Tibshirani RJ. An Introduction to the Bootstrap. New York: Chapman and Hall; 1993.

29. Martin LR, Di Matteo MR, Lepper HS. Facilitation of patient involvment in care: development and validation of a scale. Behav Med. 2010;27(3):11120.

30. Tattersall MC, Gangnon RE, Karmali KN, Cullen MW, Stein JH, Keevil JG. Trends in low-density lipoprotein cholesterol goal achievement in high risk United States adults: longitudinal findings from the 19992008 National Health and Nutrition Examination Surveys. PLoS ONE. 2013;8(4), e59309.

31. Norris S, Nichols P, Caspersen C, et al. The effectiveness of disease and case management for people with diabetes: a systematic review. Am J Prev Med. 2002;22:15-38.

32. Köpcke F, Trinczek B, Majeed RW, et al. Evaluation of data completeness in the electronic health record for the purpose of patient recruitment into clinical trials: a retrospective analysis of element presence. BMC Med Inform Decis Making. 2013;13(37):1-8.

33. Hersh W, Weiner MG, Embi PJ, et al. Caveats for the use of operational electronic health record data in comparative effectiveness research. Med Care. 2013;51:S30-7.

34. O'Malley K, Cook KF, Price MD, Wildes KR, Hurdle JF, Ashton CM. Measuring diagnoses: ICD code accuracy. Health Serv Res. 2005;40:162039.

35. Holtrop JS, Potworowski G, Fitzpatrick L, Kowalk A, Green LA. Effect of care management program structure on implementation: a normalization process theory analysis. BMC Health Serv Res. under review.

36. Holtrop JS, Potworowski G, Fitzpatrick L, Kowalk A, Green LA. Understanding effective care management implementation in primary care: a macrocognition perspective analysis. Implement Sci. 2015;10:122. 